\title{
Analysis and design of information systems news portal citizen journalism Sumba-Indonesia as local content promotion media
}

\author{
Jefonses Yarsian Pote ${ }^{1, *}$ \\ Universitas Kristen Wira Wacana Sumba \\ ${ }^{1}$ jefonses@unkriswina.ac.id* \\ * corresponding author
}

\begin{abstract}
Citizen journalism is a journalistic activity undertaken by a person or group. So far, information on the potential of the Sumba Island has not been evenly distributed because there is unequal information on the Sumbanese community and information on potential in eastern Sumba. The purpose of this research is to provide media for the citizens of Sumba in providing any information about local content in Sumba Island such as information on agriculture, plantation, forestry, tourism, cultural information, social information, political information, law, and human rights. The methodology used to build this system is the Waterfall Model. This model is an approach to software development, with several stages, namely: System Engineering, Analysis, Design, Encoding, Testing, and Maintenance. The development concept used is Model-View-Controller or MVC is a method to create an application with separate data (see) and the corresponding way (Controller). In the implementation of framework in the application of website-based architecture MVC. MVC is developing a major component-based application that builds an application such as data manipulation, user interface, and parts that become controls in a web application.
\end{abstract}

\author{
Keywords: \\ Information Systems \\ MVC Concepts \\ Citizen journalism \\ Sumba Indonesia
}

\section{Introduction}

The development of technology at this time more rapidly so as to improve the ease and facilities as support of these developments. Information technology plays an important role in conveying messages in both print and electronic media. One of them is the internet media as one of the development of technology in the present. Obviously, this time the internet is superior to the media in the previous period. In today's information age, an information system is needed that can meet the need for fast and precise information for many people. Of course with distance and time is no longer a constraint. The growing technology allows people to connect with anyone and anywhere, where in the past it was impossible to do in seconds like now.

Citizen Journalism is a journalistic activity conducted by a person or an ordinary person is not a person who is the field he did. Citizen Journalism closer to a person and society to be able to make every individual as if a journalist. Where they are able to report and inform events that are in their environment to the public. Citizen Journalism today or in the modern era that is so fast in all things and free to make an information or news that is now no longer only recommended for journalists. But now, citizens and the general public can preach an incident around them to audiences with Citizen Journalism media. now the media is increasingly popular among the general public, especially the world of journalism or journalism. Citizen Journalism is now one tool for the community to explore the ability to convey information to a large audience through this medium. Citizen Journalism seems to be a new medium that can be a bridge or tool of the general public to express their love or hobby to the world of journalism with now they are given a facility to explore their hobby.

Sumba Island has tremendous potential in certain fields. Development of agriculture sector, forestry, marine and fishery, livestock, plantation, and mining and energy in East Sumba Regency is a sector that plays an important role in economic structure in East Sumba Regency. Food is the most vital human need, therefore food sufficiency for the needs of the population should always be available in relation to the ever-increasing population from year to year, resulting in higher demand for food. Types of food crops in East Sumba are rice, corn, soybeans, cassava and tuber yields. In 2013, the 
area of paddy field and paddy fields increased from 12,394 hectares and 3,983 hectares in 2012 to 16,513 hectares and 6,054 hectares in 2013. This is due to the increase of harvested area to 12,629 ha for rice paddy and 4,382 for paddy fields with grain production and rice production also increased. (Source: Dinas Perkebunan Kab. Sumba Timur 2014)

Forests are a very important natural resource from the economic and ecological side. The contribution of forestry sub-sector to the formation of PDRB of East Sumba Regency is still relatively small when compared with other sub-sectors in agriculture sector. However, given the importance of ecological balance, the development and maintenance of the conservation of natural resources and the environment is inevitable to be developed given the current issue of global warming and environmental issues not only become a national issue but become an international issue. In addition, the natural conditions of East Sumba's environment require immediate handling given the current tend to decrease environmental degradation. The amount of Forest Land in East Sumba Regency consists of permanent production forest which decreased to 20,929.59 Ha from the previous year. The limited production forest has increased from the previous year from 15,231.1 Ha in 2012 to 84,842.94 Ha in 2013. Likewise, conversion forests from 58,422.58 Ha in 2012 increased to $65,119.30 \mathrm{Ha}$ in 2013. Results forest as an alternative income community in East Sumba tended to decline, this is in accordance with the potential of forest products that tend to be limited or because of the tight supervision of forests. (Source: Dinas Kehutanan Kab. Sumba Timur 2014)

So far, the dissemination of information on the potential on the island of Sumba has not been evenly distributed. The uneven distribution of information to the Sumbanese community and the lack of information on the potential in eastern Sumba makes the community more difficult to develop in the current information technology era. To convey information quickly and accurately required cooperation between various parties, especially between the renderer of information and accessing information. It is expected that in the development of this information system Sumba society plays an active role in presenting the latest information, update and most needed other communities, especially if the Local Government can support this information system. The social life of society here is very much needed since such life in the present is very difficult to find in society. Sharing for others is a beauty. In the development of technology, especially internet media, a website is needed to provide any information that would be given and needed by a wide audience. One of the application of webbased information system is Information System News Portal Citizen Journalism Sumba. The application of this information system is a medium for Sumba residents wherever they are to collectively provide information about the ins and outs of Sumba Island such as information on agriculture, plantation, forestry, tourism, cultural information, social information, political information, law, human rights and so on. This is what today's society needs to be efficient and effective information.

\section{Method}

The methodology used to build this system is the Waterfall Model. This model is an approach to systematic software development, with several steps, namely: System Engineering, Analysis, Design, Coding, Testing, and Maintenance.

Stages from the Waterfall Paradigm can be seen in figure 1 .

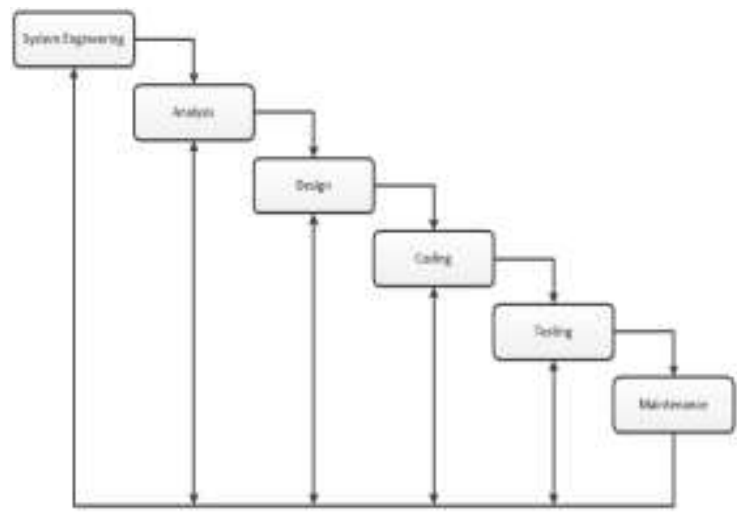

Fig. 1.Paradigma Waterfall (Classic) 
Waterfall Methodology :

- System Engineering is an early part of the work of a software project. It begins by preparing for everything that is required in the execution of the project.

- Analysis is the stage where System Engineering analyzes everything that exists in project creation or software development that aims to understand the existing system, identify problems and find solutions.

- Design, this stage is the translator stage of the needs or data that has been analyzed into a form easily understood by the user (user).

- Coding, ie translating the designed data into a predefined programming language.

- Testing is a test of the system or program after completion.

- Maintenance, the application of the system as a whole with maintenance if there is a change in structure, both in terms of software and hardware.

\section{Results and Discussion}

Table 1 shows the results analysis of systems news portal citizen journalism Sumba-Indonesia as local content promotion media.

Table 1. Results analysis of systems news portal citizen journalism Sumba-Indonesia

\begin{tabular}{|c|c|}
\hline Variable & Remarks \\
\hline \multicolumn{2}{|c|}{ Performance Analysis Results (Perfomance) } \\
\hline Throughput & $\begin{array}{l}\text { In informing the news/announcements takes a lot of time because it must be by manual ie by word } \\
\text { of mouth }\end{array}$ \\
\hline Response Time & $\begin{array}{l}\text { In delivering news/announcements to the public, the time spent in processing is long and } \\
\text { complicated, so the information provided tends to be slow and less effective. }\end{array}$ \\
\hline \multicolumn{2}{|c|}{ Information Analysis Results (Information) } \\
\hline Up to Date & $\begin{array}{l}\text { The resulting information is less up to date because the information received is still manually in the } \\
\text { delivery, and also still use the limited media. }\end{array}$ \\
\hline Accurate & $\begin{array}{l}\text { In the delivery of information, news/announcements still use the manual way of talking to some } \\
\text { people only, so the information news/announcements should be free of errors because } \\
\text { misinformation can be misleading for the recipient of the information. }\end{array}$ \\
\hline Relevant & $\begin{array}{l}\text { Because the information needed has a long process so that sometimes it is not relevant to the } \\
\text { situation. The relevant level is reduced due to situations being manually performed. }\end{array}$ \\
\hline \multicolumn{2}{|c|}{ Result of Economic Analysis (Economics) } \\
\hline Cost & The cost is quite cheap. \\
\hline Benefits & $\begin{array}{l}\text { Although the cost is cheap but the benefits of the old system can not provide benefits for the wider } \\
\text { community because the information in cannot be effective and far from expected. }\end{array}$ \\
\hline \multicolumn{2}{|c|}{ Results of Control Analysis (Controls) } \\
\hline Security & $\begin{array}{l}\text { With the control, then the tasks or performance of the disturbed can be overcome. In news } \\
\text { notification / announcement just done one person by way of input data into the website. }\end{array}$ \\
\hline \multicolumn{2}{|c|}{ Results of the Efficiency Analysis (Efficiency) } \\
\hline $\begin{array}{l}\text { Use of } \\
\text { resources }\end{array}$ & In making the information manually requires a long process. \\
\hline $\begin{array}{l}\text { The results } \\
\text { obtained }\end{array}$ & If the use is still manually, causing relatively longer working time. \\
\hline \multicolumn{2}{|c|}{ Results of Service Analysis (Service) } \\
\hline $\begin{array}{l}\text { Variety of } \\
\text { information }\end{array}$ & $\begin{array}{l}\text { Because still using the manual way, so the variety of information received is still less than the } \\
\text { maximum. }\end{array}$ \\
\hline $\begin{array}{l}\text { Ease of } \\
\text { information }\end{array}$ & $\begin{array}{l}\text { To obtain information while still using the old system, still difficult because of the limited variety of } \\
\text { information presented. }\end{array}$ \\
\hline
\end{tabular}

Context diagram is a separate event of a data flow diagram. Where one circle represents the whole system. Information System Portal News Citizen Journalism Sumba has 3 entities consisting of Admin, Editor, End User. Admin has access rights to the system between them, Identitas Website, Menu Website, Halaman Baru, Berita, Kategori Berita, Tag Berita, Komentar, Berita, Kata Jelek, Berita Foto, Galeri, Berita Foto, Video, Playlist Video, Tag Video, Komentar Video, Iklan Layanan, 
Iklan Home, Iklan Sidebar, Logo Website, Template Website, Background Website, Agenda, Jajak Pendapat, Pesan Masuk, Manajemen User, and Manajemen Modul (Figure 2).

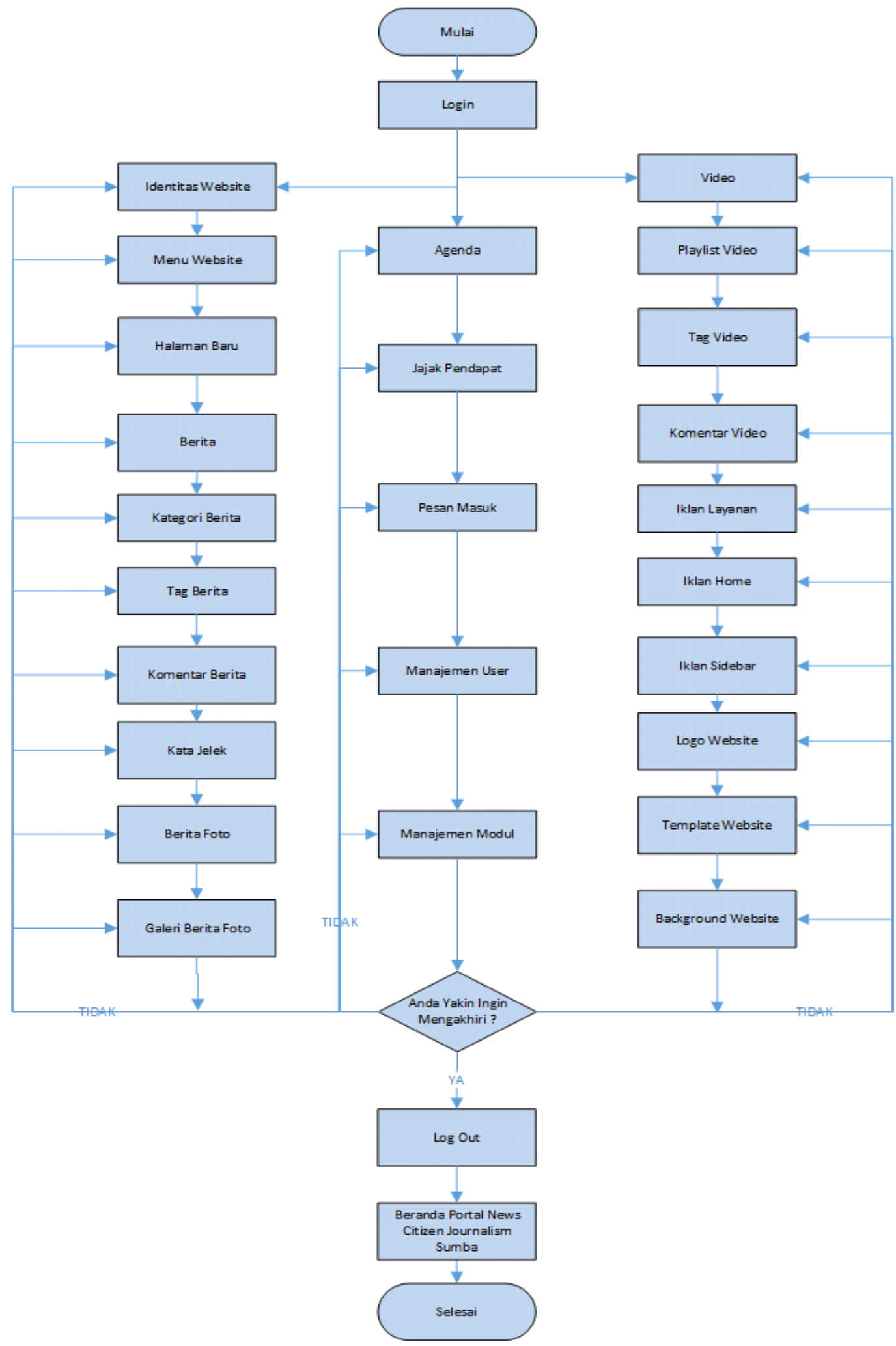

Fig. 2.Flowchart Sistem Portal News Citizen Journalism Sumba

Data Flow Diagrams (DFD) are often used to describe an existing system or a new system that will be developed logically without considering the physical environment in which data flows (e.g. by telephone, mail and so on) or the physical environment in which the data will be stored (Figure 3). 


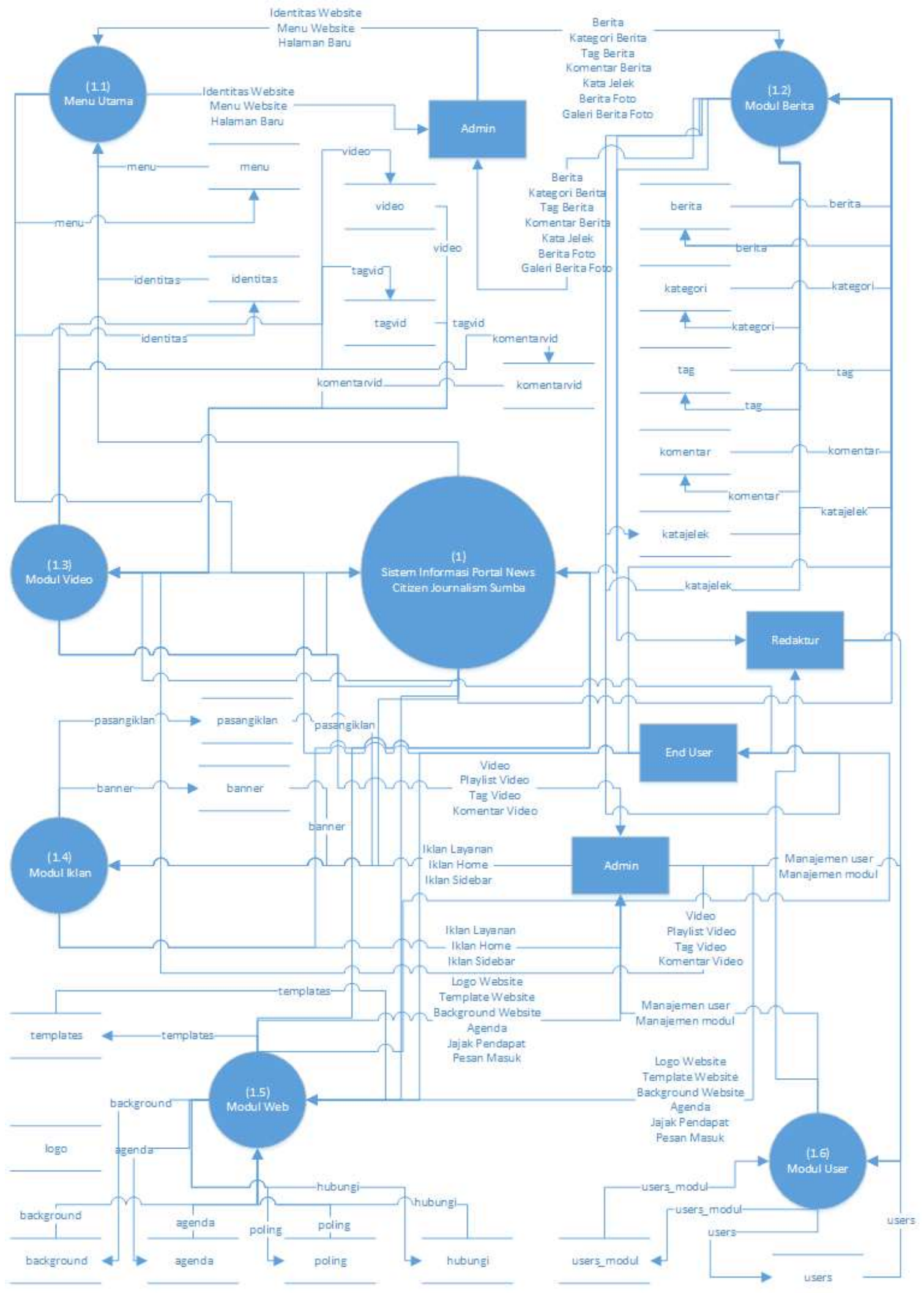

Fig. 3.Data Flow Diagram (DFD) Level 1 Portal News Citizen Journalism Sumba

In Data Flow Diagram (DFD) Level 1 News Portal Citizen Journalism Sumba consists of seven processes, in general, involving storage-storage. Terminator which consists of Admin, Editor, and End User. 
The process of data flow diagram of the system is, proses (1) Sistem Informasi Portal News Citizen Journalism Sumba, proses (1.1) Menu Utama, proses (1.2) Modul Berita, proses (1.3) Modul Video, proses (1.4) Modul Iklan, proses (1.5) Modul Web, proses (1.6) Modul User.

Table Relational News Portal Citizen Journalism Sumba is seen in Figure 4.

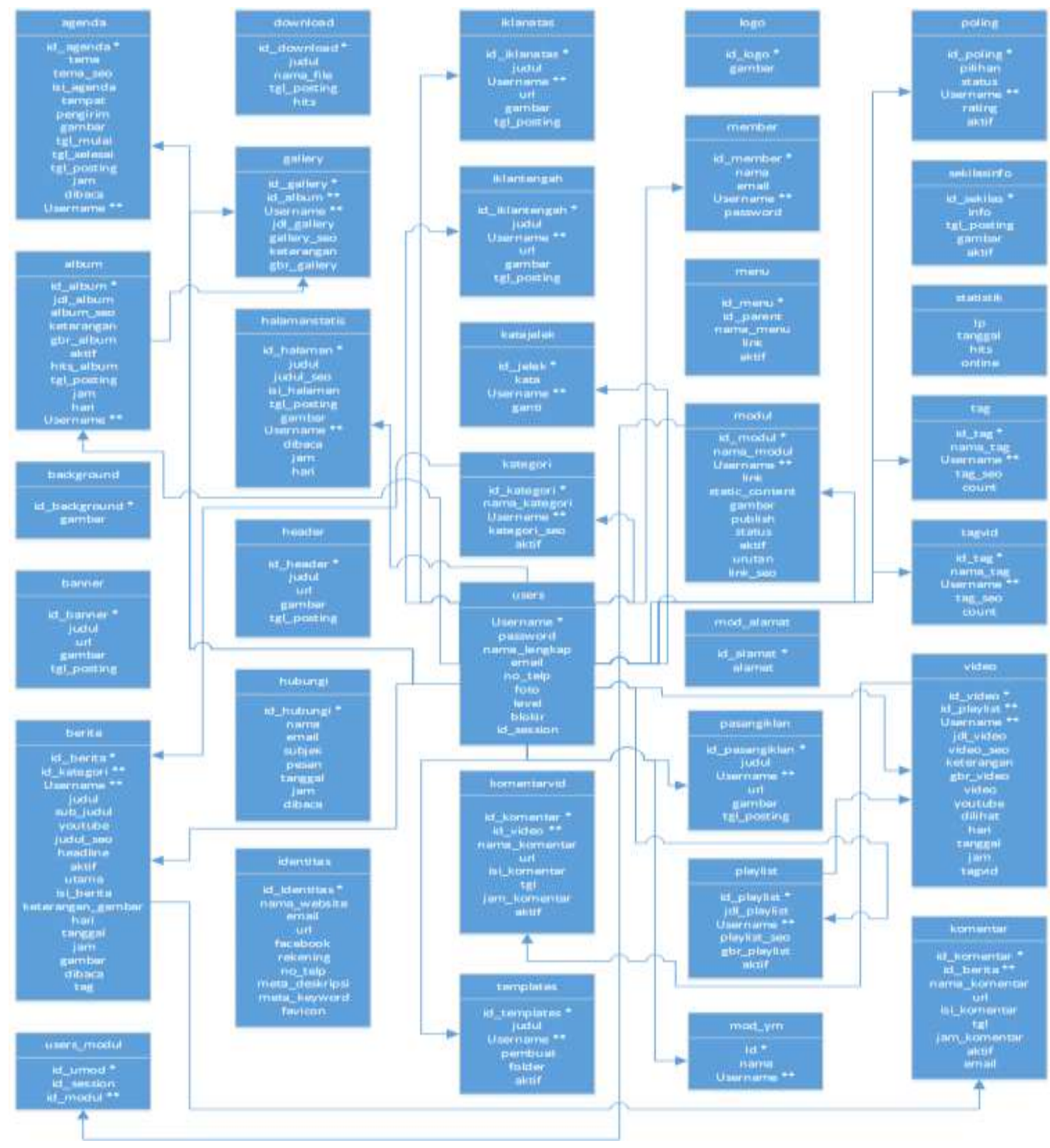

Fig. 4. Table Relational

\section{CONCLUSION}

The result of the research concludes the development of News Portal of Citizen Journalism of Sumba based on analysis of system weakness using PIECES analysis which has done require integral and mature planning not only focusing on technical matters but also designing support system including its management organization, management of usage and utilization, and standard procedures related to the utilization of existing information systems. The design of Information System Portal of Citizen Journalism Portal of Sumba with several limitations are (Flowchart system, Context Diagram, Data Flow Diagram (DFD), Entity Relationship Diagram (ERD), Inter-Table Relation and table structure design. Information System Portal News Citizen Journalism Sumba has 3 entities consisting of Admin, Editor, End User. In Data Flow Diagram (DFD) Level 1 News Portal Citizen Journalism 
Sumba consists of seven processes, in general, involving storage-storage. Terminator which consists of Admin, Editor, and End User.

The author realizes that this research is still a lot of shortcomings, therefore it is expected for researchers who want to do development of this research with the same problems suggested can be developed with the suggestion that is implementing the design of systems created using MVC concept.

\section{Acknowledgment}

The authors express their gratitude to all those who have provided financial support and moral support for this research.

\section{References}

[1] Al, Fatta, Hanif,. 2007. analisis dan perancangan sistem informasi untuk keunggulan bersaing perusahaan dan organisasi modern. Andi Offset, Yogyakarta

[2] Arief, Ramadhan,. 2006, SGS : Pemr.Web Database PHP\&MySQL, halaman 70. Elex Media Komputindo.

[3] Fany, Ariasari,. 2007, Panduan Praktis Bikin Blog dengan Wordpress, halaman 10. Media Kita.

[4] Hasibuan, Zainal A,. 2007, Metodologi Penelitian Pada Bidang Ilmu Komputer Dan Teknologi Informasi : Konsep, Teknik dan Aplikasi, Jakarta: Fakultas Ilmu Komputer Universitas Indonesia.

[5] Jogiyanto, HM. 2006, Sistem Informasi Strategik untuk keunggulan kompetitif, Memenangkan persaingan dengan sistem teknologi informasi, Andi Offset, Yogyakarta

[6] Krasner, Glenn E.; Pope, Stephen T. 1988. "A cookbook for using the model-view controller user interface paradigm in Smalltalk-80". The Journal of Object Technology (SIGS Publications). Also published as "A Description of the Model-View-Controller User Interface Paradigm in the Smalltalk-80 System" (Report), ParcPlace Systems; Retrieved 2012-06-05.

[7] Laudon K.C. dan Laudon J.P., 2008, Sistem Informasi Manajemen, Mengelola Perusahaan Digital, Salemba Empat, Jakarta

[8] Leff, Avraham; Rayfield, James T. 2001. Web-Application Development Using the Model/View/Controller Design Pattern. IEEE Enterprise Distributed Object Computing Conference. pp. 118-127.

[9] Moore, Dana et al. 2007. "Since the origin of MVC, there have been many interpretations of the pattern. The concept has been adapted and applied in very different ways to a wide variety of systems and architectures." Professional Rich Internet Applications: Ajax and Beyond

[10] O'Brien, J.A. dan Marakas, G.M, 2007, Introduction to Information Systems, McGraw Hill, New York.

[11] Pressman R. S., 2014. Software Engineering. A PRACTITIONER'S APPROACH. FIFTH EDITION. Boston Burr Ridge, IL Dubuque, IA Madison, WI. New York 